\title{
World Health Organization Strategies to Reduce Smoking
}

\author{
Estrategias de la Organización Mundial de la Salud para reducir el tabaquismo
}

Nadia Aguilar Castro ${ }^{a}$, Eduardo Hernández Martínez ${ }^{b}$

Received: 14/08/2018, Accepted: 13/11/2018, Published: 05/01/2019

\begin{abstract}
:
Today, tobacco is a serious public health problem considered a risk factor in chronic diseases and its complications. Tobacco habit is a risk factor completely modifiable, so it is important to quit this bad habit at all ages. Due to tobacco epidemic, the World Health Organization (WHO) established the Framework Convention on Tobacco Control (FCTC) and the Monitor, Protect, Offer, Warn, Enforce and Raise (MPOWER) Brochures and the importance of the use of social marketing as a tool of educational communication to transmit health information clearly, and promote healthy lifestyles, reinforce knowledge, attitudes or behaviors.
\end{abstract}

Keywords:

Tobacco, Marketing, Public policies in health, Framework Convention on Tobacco Control

\section{Resumen:}

Actualmente, el tabaco es un grave problema de salud pública, considerado un factor de riesgo en las enfermedades crónicas y sus complicaciones. El hábito tabáquico es un factor de riesgo totalmente modificable, por lo que es importante dejar este mal hábito en todas las edades. Debido a la epidemia de tabaquismo, la Organización Mundial de la Salud (OMS) estableció el Convenio Marco para el Control del Tabaco (FCTC) y los folletos Vigilar, Proteger, Ofrecer, Advertir, Hacer cumplir y Aumentar (MPOWER) y la importancia del uso de mercadotecnia social como una herramienta de comunicación educativa para transmitir información de salud de forma clara, y promover estilos de vida saludables, reforzar conocimientos, actitudes o comportamientos.

Palabras Clave:

Tabaco, Mercadotecnia, Políticas públicas en salud, Convenio Marco para el Control del Tabaco

\section{INTRODUCTION}

The tobacco plant was discovered by the Europeans in the first trip of Columbus to the New Continent in 1492. First it was valued as a medicinal plant and later it was incorporated in the society's consumption as a source of pleasure, custom or habit. In the consumption of tobacco, several agents are mixed, such as the political-economic power, the manufacturers, the producers, and the consumers.
Worldwide, chronic noncommunicable diseases cause about two thirds of total deaths. Four categories of diseases, cardiovascular, chronic respiratory, cancer and diabetes are the main responsible for morbidity and mortality from noncommunicable diseases. These four types of noncommunicable diseases can be largely prevented or controlled by effective interventions that tackle common risk factors, such as tobacco use, unhealthy diet, physical inactivity and harmful use of alcohol; also by an early detection and treatment. ${ }^{2}$ 
The three main risk factors responsible for the global burden of morbidity were: high blood pressure, tobacco consumption and household air pollution from solid fuels. ${ }^{3}$ Five priority interventions have been recommended to reduce this trend:

1. Control of tobacco.

2. Reduction of salt consumption.

3. Better diet and physical activity.

4. Reduction of dangerous alcohol consumption.

5. Access to essential medicines and technology. ${ }^{4}$

Within tobacco control, the World Health Organization (WHO) argues the right of all people to enjoy health. In 2003, the WHO developed the Framework Convention on Tobacco Control (FCTC) in response to the tobacco epidemic and came into force as of February 2005, it argues that the spread of this epidemic is favored by several factors. ${ }^{5}$ Seven years later, it integrates the Monitor, Protect, Offer, Warn, Enforce and Raise (MPOWER) brochure strategy as a support measure and recommendations for countries. ${ }^{6}$

Smoking tobacco reduces life expectancy and is associated with chronic diseases, such as: lung, larynx, kidney, bladder, stomach, colon, oral cavity and esophagus cancers; it is also related to leukemia, chronic obstructive pulmonary disease, ischemic heart disease, abortions and premature births. ${ }^{7}$

Mexico signed and ratified the FCTC on March 21, 2003, but as of 2011 the Ministry of Health affirms that Mexico does not escape the globalization of the tobacco epidemic, which continues to be a serious public health problem because it shows a tendency to increase the frequency of consumption and the exposure of tobacco smoke since the diseases related to consumption continue in our country among the leading causes of mortality. ${ }^{8}$ The objective of this Convention and its protocols is to protect present and future generations from tobacco consumption and exposure to tobacco smoke against the health, social, environmental and economic consequences, providing a framework for tobacco control measures to be applied at the regional, national, and international levels to continuously and substantially reduce the prevalence of tobacco use and exposure to tobacco smoke. ${ }^{9}$

\section{EPIDEMIOLOGY}

Tobacco use is the main preventable cause of death. Every year it causes the death of more than 7 million people, and, estimated data of the WHO in 2030 will cause the death of 8 million people. ${ }^{10}$

In developed countries 2.43 million people die, and 2.41 million in developing and poor countries, $84 \%$ of deaths caused by tobacco use, in developing countries, are men. ${ }^{11}$

In Mexico, $16.4 \%$ (14.3 million) of adults aged 15 years old and older currently smoke tobacco; $25.2 \%$ of men (10.6 million) and $8.2 \%$ of women (3.8 million). In total, $7.6 \%$ were daily smokers (men $11.9 \%$, women $3.6 \%$ ), while $8.8 \%$ were occasional smokers (men 13.3\%, women $4.6 \%)^{12}$

In Spain, the consumption of tobacco in women has been associated with different types of cancer such as breast, lung, oral, throat, larynx, esophagus, stomach, pancreas, gallbladder, kidney, cervix and uterus cancer. ${ }^{13}$

Although Mexico has made an effort in the epidemiological surveillance of smoking, today it does not have a national surveillance system that responds to the information requirements of the FCTC and allows estimating the indicators to evaluate the implementation of the policy package MPOWER. This surveillance system must be transversal, integral, global and sustainable over time to know the impact, measure it and control it. ${ }^{12}$ In Mexico, 118 people die every day due to tobacco consumption, approximately 43,246 people per year. ${ }^{7}$

In the Global Survey of Smoking in Adults Mexico conducted in 2015 it was observed that the prevalence of current smoking among Mexican adults did not show a statistically significant change between 2009 and 2015 (15.9\% vs $16.4 \%$ ) or by sex (men $24.8 \%$ vs $25.2 \%$, women $7.8 \%$ vs. $8.2 \%) .{ }^{12}$ Within the distribution of the age of onset of daily smokers among those who had ever smoked daily from 20 to 34 years, showed a statistically significant reduction from 17.6 years (2009) to 16.5 years (2015) in general (men, 16.9 to 16.4 , women, 19.6 to 
17.1). Likewise, the average number of cigarettes smoked per day was reduced from 9.3 in 2009 to $7.7 \mathrm{cig} /$ day in 2015 (men, 9.7 vs $8.0 \mathrm{cig} /$ day, and women, 8.4 vs 6.8 cig / day). This decrease was statistically significant in total and in men, but not in women. ${ }^{12}$

Among those who work indoors or in closed areas, $17.0 \%$ (3.9 million) were exposed to second-hand smoke in their workplaces. Among adults who visited several public places in the past 30 days, exposure to tobacco smoke was $72.7 \%$ in bars and clubs, $42.4 \%$ in universities, $24.6 \%$ in restaurants, $24.7 \%$ in public transport, $14.0 \%$ in government buildings, $13.7 \%$ in schools and $5.2 \%$ in facilities that provide health services. ${ }^{4}$ Returning to this $5.2 \%$ in facilities that provide health services, it is very important to raise awareness among workers and users that, in health areas, they should be $100 \%$ smoke free. ${ }^{14}$

\section{WHO FRAMEWORK CONVENTION ON TOBACCO CONTROL (WHO FCTC)}

International instrument for tobacco control because of resolution of the World Health Assembly (WHA4811) in May 1995, the first treaty based on scientific evidence to carry out a normative strategy that guarantees the right of people to enjoy health. Preventing the advance of the tobacco epidemic, through the creation of the FCTC integrated by general measures of demand reduction, application of taxes, education, communication, packaging and labeling of tobacco. As well as support measures with the MPOWER Brochures. ${ }^{9}$

It is the first treaty that develops a normative strategy on addictive substances and which reaffirms the right of all people to enjoy health with the objective of reducing the prevalence of tobacco use, as well as protecting present and future generations form the consequences generated by tobacco consumption and the exposure to smoke in the health, social, economic and environmental fields. The Convention entered into force on February 27, 2005, 90 days after 40 States had signed it or had ratified, accepted or approved it. ${ }^{15}$ The measures related to the reduction of tobacco demand are included in the articles 6 to 14 of the Framework Convention on Tobacco Control, explained below:
Article 6. Recognizes the application of a tax policy in increasing prices to reduce tobacco consumption especially in young people, as well as prohibit or restrict the sale or importation of duty-free products or customs duties by travelers. ${ }^{9}$

Article 7. Legislative, executive, and administrative measures are necessary to comply with articles 8 to $13 .{ }^{9}$ Article 8. Protection against the exposure of tobacco smoke in closed public places, public transport and work centers since tobacco smoke causes death, disease and disability. ${ }^{15}$

Article 9. The surveillance of national competent authorities to comply with the regulations on tobacco products. $^{4}$

Article 10. Regulations where manufacturers or importers provide information regarding the toxic components of tobacco products and their emissions. ${ }^{9}$

Article 11. Surveillance where the packages and labels of the products do not provide a false product regarding their characteristics, effects and health risks, as well as showing sanitary warnings which must be approved by the competent authorities, must be clear, large, visible, occupy $50 \%$ or more of the surface and in no case less than $30 \%{ }^{16}$

Article 12. Promote and strengthen the awareness of health risks and the benefits of quitting tobacco use through communication tools and comprehensive programs. ${ }^{16}$

Article 13. Prohibit all forms of advertising, promotion and sponsorship of tobacco by restricting the use of incentives that encourage the purchase of the product. As well as restriction by radio, television, print media and other media, such as Internet. ${ }^{17}$

Article 14. Promotion programs aimed at promoting the cessation of tobacco use in educational institutions, health units, workplaces and sporting environments. Counselling services on cessation of tobacco use, as well as establishing health care centers for prevention, treatment and rehabilitation. ${ }^{18}$

\section{MPOWER BROCHURES}


The next strategy adopted by the WHO was the use of MPOWER brochures, which emerged seven years after they were included in the agreement to help fulfill some obligations of the Convention. They were developed to reinforce support with basic data and recommendations related to each of the measures. ${ }^{19}$

The definition of the MPOWER acronym is: Monitor, Protect, Offer, Warm, Enforce and Raise.

- Monitor tobacco use and prevention policies.

- Protect people from tobacco smoke.

- Offer help to quit tobacco use.

- Warn about the dangers of tobacco.

- Enforce bans on tobacco advertising, promotion and sponsorship.

- Raise taxes on tobacco. ${ }^{20}$

The brochures contain the following topics:

- Monitor tobacco consumption and prevention policies.

- Protect the population from tobacco smoke.

- Offer help to quit smoking.

- Warn about the dangers of tobacco.

- Enforce prohibitions on tobacco advertising, promotion and sponsorship.

- Increase taxes on tobacco. ${ }^{20}$

In the WHO report of 2015 on the World Tobacco Epidemic, it is reported that in more than half of the countries in the world a MPOWER measure is applied to $40 \%$ of the world's population (2.8 billion people). The report focuses on the MPOWER measure that has experienced the least progress: $(R)$ Increase taxes on tobacco, reports that only one in 10 people live in the 33 countries that impose cigarette liens of more than $75 \%$ of their retail price; thus, this is the least applied MPOWER measure and the one that has progressed the least since $2007 . .^{19}$

In 2017, almost two thirds of the countries report that $63 \%$ of the world's population have at least one MPOWER measure at the highest level of compliance, 4,700 million people are protected by at least one normative intervention. $^{8}$

Now we can see the importance of these strategies or regulations taken by the WHO in trying to reduce the advertising that encourages the consumption of tobacco. Tobacco companies, before entering the framework in force, used all the marketing strategies to promote their tobacco products, advertising on television, radio, magazines, using promotional items, sponsorships, etc., now that they are regulated and prohibited the companies have looked for new not-regulated markets to advertise their products. ${ }^{17}$

Efforts to control advertising have been conveniently successful in traditional media such as television, radio and the written press but insufficient in other media such as the Internet and videogames, which is the new way of marketing and advertising tobacco addressed to young people $^{21}$. It is a health problem mainly because the age at which the smoking habit starts is each time at younger ages, the average age of onset of tobacco use is 13.7 years old in adolescents and 17.4 years old in adults. ${ }^{22}$ In the same way, marketing can also be used to fight against smoking through social marketing, by generating social campaigns ${ }^{23}$ that can be used in the design of strategies and public interventions in order to increase health and well-being levels of citizens ${ }^{24}$. These mass media communication campaigns are also a useful tool to achieve greater learning and public support for smokefree spaces, through behavioral changes and the perception of people..$^{25}$

\section{CONCLUSIONS}

It is important that countries continue to progressively move towards the full implementation of the FCTC and the creation of intervention programs in social marketing campaigns that are aimed at promoting more positive behaviors for health and reducing those that may deteriorate it, such as smoking, based on the recommendations and basic data included in the MPOWER brochures. 

humo de tabaco [document on the Internet]. Ginebra: OMS; 2008. [cited may 29, 2018]. Available from: http://www.who.int/tobacco/mpower/publications/es/

16. Organización Mundial de la Salud. Advertir sobre los peligros del tabaco. [document on the Internet]. Ginebra: OMS; 2008.

\section{REFERENCES}

1. Esteo E. Campañas de comunicación masiva antitabaco: equilibrio entre consumo, salud e intereses económicos. Rev. Esp. Comun. Salud. 2013;4(1):65-71. prevención y el control de las enfermedades no transmisibles en las Américas 2013-2019. Washington (DC): OPS; 2014.

3. Pichon-Riviere A, Alcaraz A, Bardach A, Augustovski F, Caporale J, Caccavo F. Carga de enfermedad atribuible al tabaquismo en Argentina [Internet]. Buenos Aires, Argentina: IECS; 2013. Documento técnico Instituto de efectividad Clínica y Sanitaria: 7. Available from: http://www.iecs.org.ar Reynales-Shigematsu LM. El control del tabaco, estrategia esencial para reducir las enfermedades crónicas no transmisibles. Salud. Pública. Mex. 2012;54(3):323-31.

5. World Health Organization. History of the World Health Organization Framework Convention on Tobacco Control. Geneva: WHO; 2009.

Blanco A, Sandoval RC, Martínez-López L, Caixeta R. Diez años del Convenio Marco de la OMS para el Control del Tabaco: avances en las Américas. Salud. Publica. Mex. 2017;59 (suppl. 1): S117-S125.

7. Sánchez AJG, Lira Mandujano J. Revisión sobre los factores relacionados con el consumo de tabaco en la mujer. Caleidoscopio. 2016;(34):95-118.

8. Organización Mundial de la Salud. Informe OMS sobre la epidemia mundial de tabaquismo, 2017. Ginebra: OMS; 2017.

9. Organización Mundial de la Salud. Convenio Marco de la OMS para el Control del Tabaco. Ginebra: OMS; 2003.

10. World Health Organization. [homepage on the Internet] Geneva: WHO; c2018 [update 2018 Mar 9; cited 2018 May 29]. [about 4 screens]. Available from: http://www.who.int/es/newsroom/fact-sheets/detail/tobacco

11. Suárez Lugo N. Tabaco o salud: una decisión social. Horiz. Sanitario. 2004;3(2):1-21.

12. Secretaría de Salud. Encuesta Global de Tabaquismo en Adultos México 2015. México: Secretaría de Salud; 2016.

13. Martínez-Acitores IS, Rubio J, Espiga I, Alonso B, Blanco J, Cortés M, et al. Plan Nacional de Prevención y Control del Tabaquismo. Rev. Esp. Salud. Pública. 2003;77(4):441-73.

14. Secretaría de Salud. Encuesta Nacional de Consumo de Drogas en Estudiantes 2014: Reporte de Tabaco. México: Secretaría de Salud; 2015.

[cited may 29, 2018]. Available from: http://www.who.int/tobacco/mpower/publications/es/

17. Organización Mundial de la Salud. Hacer cumplir las prohibiciones sobre publicidad, promoción y patrocinio del tabaco. [document on the Internet]. Ginebra: OMS; 2008. [cited may 29, 2018]. Available from: http://www.who.int/tobacco/mpower/publications/es/

18. Organización Mundial de la Salud. Ofrecer ayuda para dejar el tabaco. [document on the Internet]. Ginebra: OMS; 2008. [cited may 29, 2018]. Available from: http://www.who.int/tobacco/mpower/publications/es/

19. Organización Mundial de la Salud. Informe OMS sobre la epidemia mundial de Tabaquismo, 2015. Aumentar los impuestos al tabaco. Ginebra: OMS; 2015.

20. Organización Mundial de la Salud. Vigilar el consumo de tabaco y las políticas de prevención. [document on the Internet]. Ginebra: OMS; 2008. [cited may 29, 2018]. Available from: http://www.who.int/tobacco/mpower/publications/es/

21. Barrientos-Gutiérrez T, Barrientos-Gutiérrez I, ReynalesShigematsu LM, Thrasher JF, Lazcano-Ponce E. Se busca mercado adolescente: internet y videojuegos, las nuevas estrategias de la industria tabacalera. Salud. Pública. Mex. 2012;54(3):303-14.

22. Rodríguez-Ramírez JM, Salas-González TL, Ruiz-Zúñiga BJ, Flores-Ortíz FM, Durán-Sánchez PE, Gómez-Cardona JP. Creencias de los escolares de educación primaria sobre los efectos del consumo de tabaco. Rev. Enferm. Inst. Mex. Seguro. Soc. 2016;24(1):55-9.

23. Góngora LH. Mercadotecnia social: una herramienta necesaria para la promoción de salud. Medisan 2014;18(5):684-94.

24. De la Peña-De León A, Amezcua-Núñez JB, Hernández-Bonilla A. La promoción de estilos de vida saludable aprovechando los espacios públicos. Horiz. Sanitario. 2017;16(3):201-10.

25. Villalobos V, Ortiz O, Thrasher JF, Arillo E, Pérez R, Cedillo C, et al. Mercadotecnia social y políticas públicas de salud: campaña para promover espacios libres de humo de tabaco en México. Salud. Pública. Mex. 2010;52(supl 2): S129-S137 